\title{
Efektifitas Terapi Caring Support Neobil terhadap Perubahan Kadar Bilirubin Serum Total Hyperbilirubinemia pada Neonatus di Rumah Sakit Dustira Cimahi
}

\author{
An'nisaa Heriyanti ${ }^{1 *}$, Restuning Widiasih ${ }^{2}$, Murtiningsih ${ }^{3}$ \\ ${ }^{1}$ Magister Keperawatan, STIKES Jenderal Achmad Yani, Indonesia: annisaanisa03@gmail.com \\ ${ }^{2}$ Departemen Keperawatan Maternitas, Universitas Padjadjaran, Indonesia \\ ${ }^{3}$ Magister Keperawatan, STIKES Jenderal Achmad Yani, Indonesia \\ *(Korespondensi e-mail: annisaanisa03@gmail.com)
}

\begin{abstract}
ABSTRAK
Pemberian ASI kurang dan lambatnya perawatan terapi cahaya dapat memperberat akumulasi bilirubin di dalam darah. Tujuan penelitian ini untuk mengetahui efektivitas terapi caring support NEOBIL terhadap perubahan nilai kadar bilirubin serum total hyperbilirubinemia fisiologis pada neonatus di Rumah Sakit Dustira Kota Cimahi. Desain penelitian menggunakan quasi experiment dengan non-equivalent control group design pret-test post-test. Sampel diambil secara consecutive terbagi menjadi kelompok intervensi (29 responden) dan kelompok kontrol (29 responden) sesuai dengan kriteria inklusi. Instrumen penelitian yang digunakan berupa lembar observasi tindakan dan alat mesin TMS 24i \& 50i. Data dianalisa menggunakan paired t-test dan independent t-test. Hasil menunjukan rata-rata kadar bilirubin serum total setelah pemberian intervensi pada kelompok intervensi $(9,17)$ sedangkan kelompok kontrol $(11,23)$ antara kedua kelompok terdapat penurunan yang bermakna ( $p$-value 0,002$)$. Berdasarkan hasil penelitian terapi caring support NEOBIL lebih efektif secara statistik membantu terapi cahaya menurunkan nilai kadar bilirubin serum total.
\end{abstract}

Kata kunci: Bilirubin, Hyperbilirubinemia Fisiologis, Neonatus

Abstract

Less breast feeding and slow treatment of light therapy can strengthen the accumulation of bilirubin in the blood. The purpose of this research is to know the effectiveness of caring therapy NEOBIL to change the value of bilirubin levels of serum hyperbilirubinemia total physiological in neonatal in Dustira Hospital, Cimahi City. The research design uses a quasi-experiment with a non-equivalent control group design pre-test post-test. Samples were taken consecutive divided into intervention groups (29 respondents) and control groups (29 respondents) following the criteria of inclusion. The research instrument used is the action observation sheet and machine tool of TMS 24i \& 50i. Data is analyzed using a t-test paired and independent t-test. Results showed average levels of total serum bilirubin after intervention in the intervention group (9.17) while the control group (11.23) between the two groups was a meaningful decline (P-value 0.002). Based on the results of Caring therapy Research support NEOBIL more effectively statistically help light therapy lowers the value of total serum bilirubin.

Keywords: Bilirubin, Jaundice, Neonates, Physiologic hyperbilirubinemia 


\section{PENDAHULUAN}

Berdasarkan data (Badan Kependudukan dan Keluarga Berencana Nasional et al., 2018), penyebab kematian neonatal salah satunya adalah kelainan hematologi/hiperbilirubinemia merupakan penyebab nomor lima morbiditas neonatal dengan prevalensi sebesar 5,6\% setelah gangguan nafas, prematuritas, sepsis, dan hipotermi. Data terbaru prevalensi hiperbilirubinemia berat $(>20 \mathrm{mg} / \mathrm{dL})$ adalah $7 \%$, dengan hiperbilirubinemia ensefalopati akut sebesar $2 \%$. Dari data yang diperoleh, neonatus yang menderita hiperbilirubinemia cukup bervariasi, namun menjadi salah satu fenomena klinis yang paling sering ditemukan pada bayi dalam minggu pertama kehidupan dan merupakan alasan dari $75 \%$ kejadian neonatus yang mendapatkan perawatan pada minggu pertama setelah kelahiran. Walaupun peningkatan bilirubin pada neonatus merupakan kondisi yang sering terjadi, tetapi pada kondisi akumulasi bilirubin yang tinggi di dalam darah dan penanganan yang lambat akan berdampak negatif pada kesehatan neonatus.

Dampak dari peningkatan bilirubin yang paling berat bila tidak tertangani dengan cepat adalah ensefalopati bilirubin hingga terjadi kern ikterus dan kerusakan otak. Hiperbilirubinemia juga dapat menyebabkan gejala sisa berupa cerebral palsy, tuli nada tinggi, paralisis dan displasia dental yang sangat mempengaruhi kualitas hidup neonatus (Muchowski, 2014).

Tatalaksana hiperbilirubinemia menurut panduan WHO yaitu pemberian ASI sedini mungkin, pemberian terapi sinar (phototherapy), tranfusi tukar bila kadar bilirubin terus meningkat dan mencapai nilai tertinggi sesuai dengan berat badan neonatus sertai pemberian terapi obat-obatan medis (Ullah et al., 2016; Wong et al., 2009).

Efek samping yang dapat ditimbulkan, seperti diare, dehidrasi, ruam kulit, gangguan retina, hipertermia, Bronze Baby Syndromme, bahkan kemandulan pada bayi laki-laki. Selama phototherapy (terapi cahaya) bayi terpisah dari ibunya sehingga beresiko berdampak pada peningkatan stres dan emosional pada ibu dan bayi (Kianmehr et al., 2014).

Ada tiga intervensi keperawatan yang akan diaplikasikan dalam penelitian ini, untuk membantu terapi cahaya menurunkan kadar bilirubin serum total pada neonatus hiperbilirubinemia fisiologis yaitu intervensi bounding dengan cara stimulus touch, feeding management dan positioning.

Intervensi bounding stimulus touch merupakan kebutuhan dasar bayi baru lahir. Sentuhan merupakan cara sederhana ibu untuk berkomunikasi dengan bayinya. Indra peraba bayi mulai berkembang pada usia kehamilan 7 sampai 8 minggu karena itu, sentuhan ibu merupakan bahasa pertama bagi bayi dan dapat menguatkan serabut otak (sinapsis) dan sel-sel otak bayi guna mendukung fungsi otak yang optimal (Prasetyorini \& Sukesi, 2018).

Sentuhan dapat meningkatkan tonus nervus vagus (nervus $\mathrm{x}$ ), saraf ini akan meningkatkan kerja dari otot-otot sfinkter dan mengoptimalkan kerja dari kelenjar di dalam traktus intestinalis, hepar dan pankreas, meningkatkan produksi enzim pencernaan yang membantu meningkatkan penyerapan sehingga sistem kerja pencernaan lebih baik dan penyerapan makanan lebih maksimal serta meningkatkan aliran getah bening, memperlancar peredaran darah dan meningkatkan metabolisme sel. Kondisi ini dapat mempercepat ekskresi bilirubin dipecah oleh terapi cahaya. Proses ini dapat membantu mengurangi terjadinya peningkatan kadar bilirubin pada neonatus dengan mempercepat ekskresi feses (Andaruni \& Alasiry, 2018).

Intervensi ini juga memiliki efek biokimia dengan meningkatkan sistem kekebalan tubuh pada bayi dengan cara menurunkan hormon stres agar hormon kostisol tidak menghancurkan sel-sel kekebalan tubuh yang melawan virus, sehingga imunitas tubuh tetap dapat menjaga 
kekebalan tubuh tetap sehat. Kondisi ini dapat merangsang metabolisme agar racun dalam tubuh (Ayuningtyas, 2019).

Stimulus touch dalam penelitian ini menggunakan tehnik petrissage yaitu sentuhan lembut dan ringan, dan vibrasi (getaran) lembut menjadi pilihan yang tepat, karena usapan yang panjang dan lembut dapat memberikan kesenangan serta kenyamanan bagi bayi dan usapan yang pendek dan sirkuler cenderung lebih bersifat menstimulasi dengan durasi sentuhan 3-5 menit.

Manipulasi sentuhan dengan pemijatan yang dikombinasikan dengan terapi cahaya lebih efektif dalam penurunan bilirubin serum neonatus dengan meningkatkan frekuensi buang air besar pada neonatus (Lei et al., 2018; Lin et al., 2015).

Intervensi feeding management hiperbilirubinemia pada neonatus yang mendapatkan terapi cahaya. Salah satu tatalaksana hiperbilirubinemia menurut panduan WHO yaitu pemberian ASI sedini mungkin. Kebutuhan cairan akan meningkat (growth spurt) seiring dengan efek dari paparan sinar terapi cahaya, pemberian volume cairan akan ditambah dengan cara perah payudara (power pumping), asupan makan yang cukup (ASI) dapat memicu geraka pristaltik usus sehingga ekskresi bilirubin hasil pemecahan terapi cahaya dapat segera dikeluarkan (American Academy of Pediatrics Subcommittee on Hyperbilirubinemia, 2004).

Intervensi ke tiga alih baring (positioning), berfokus pada tindakan merubah posisi yang menjalani terapi cahaya. Alih baring pasien dilakukan dengan cara terlentang, miring kanan, miring kiri. Luasnya area tubuh yang terpapar sinar fototerapi dipengaruhi oleh proposionalnya ukuran tubuh yang terpapar sinar. Selain itu, perubahan posisi tubuh bayi setiap 2-3 jam dapat memaksimalkan area yang terpapar cahaya dari fototerapi. Sehingga dapat membantu memaksimalkan proses perubahan bilirubin di kapiler superfisial dan jaringan interstitial dengan reaksi paparan kimia dan oksidasi cahaya (American Academy of Pediatrics Subcommittee on Hyperbilirubinemia, 2004).

Tindakan alih baring dapat membantu dalam penurunan bilirubin serum selama terapi cahaya pada neonatus (Ningsih, 2017; Wikanthiningtyas \& Mulyanti, 2016).

Berdasarkan latar belakang di atas peneliti tertarik untuk mengembangkan penelitian tentang intervensi keperawatan khususnya dalam melakuan perawatan neonatus dengan hiperbilirubinemia fisiologis, yang sedang menjalani pengobatan terapi cahaya. Peneliti bermaksud untuk melakukan penelitian lebih lanjut untuk mengetahui apakah penggabungan dari ketiga intervensi keperawatan di atas yang diberi nama intervensi caring support NEOBIL (bounding stimulus touch, feeding management dan positioning) dapat lebih efektif mempengaruhi perubahan nilai kadar bilirubin serum total neonatus hiperbilirubinemia fisiologis sebagai kelompok intervensi dan pemberian terapi standar rutin di ruangan RS Dustira sebagai kelompok kontrol atau pembanding.

\section{METODE}

\section{Jenis Penelitian}

Jenis penelitian kuantitatif dengan analitik quasi eksperimen non-equivalent control group design, one group pre-test post-test control dan one group pre-test post-test intervention. kelompok kontrol sebagai pembanding berupa perawatan standar rutin di ruangan dan kelompok intervensi mendapat perlakuan caring support NEOBIL.

\section{Lokasi dan Waktu Penelitian}

Penelitian ini berlokasi di Rumah Sakit Dustira Kota Cimahi. Penelitian dilaksanakan pada bulan Desember 2019Januari 2020. 


\section{Populasi dan Sampel}

Populasi penelitian adalah seluruh pasien neonatus yang menderita hiperbilirubinemia fisiologis dan mendapatkan terapi cahay. Sampel pada Penelitian ini berjumlah 58 (29 kontrol dan 29 intervensi) responden dengan menggunakan metode non-probability sampling jenis consecutive sampling dengan kriteria inklusi penelitian:

1. Bayi yang berumur 3 sampai 29 hari.

2. Neonates dengan nilai bilirubin serum $\geq$ $10 \mathrm{mg} / \mathrm{dL}$ sampai $20 \mathrm{mg} / \mathrm{dL}$.

3. Neonatus tanpa komplikasi penyakit lain atau kelainan kongenital.

4. Neonatus dengan kondisi hiperbilirubinemia fisiologis yang mendapatkan perawatan terapi cahaya

5. neonatus dengan kondisi stabil, berat badan $\geq 2500$ gram dan usia gestasi $\geq 38$ minggu.

6. Neonatus lahir dengan persalinan SC maupun spontan.

7. Neonatus yang mendapatkan air susu ibu atau susu formula.

8. Ibu yang pengalaman pertama merawat bayi dengan hyperbilirubinemia.

9. Orangtua responden mengizinkan bayinya ikut serta menjadi responden.

10. ibu bersedia melakukan tindakan intervensi kepada responden.

\section{Pengumpulan Data}

Pengumpulan data dilakukan dengan menggunakan lembar observasi untuk mengamati komponen identitas, umur, berat badan, jenis kelamin, jenis persalinan, jenis pemberian makanan, dan nilai kadar bilirubin serum neonatus sebelum dan sesudah pemberian intervensi. Kadar bilirubin serum total dihitung dari sampel nilai bilirubin biofisiologi in vitro blood vena menggunakan alat ukur mesin jenis TMS 24i dan TMS 50i yang tersedia di tempat penelitian. Peneliti mengurus izin etik di komite etik STIKES jenderal Achmad Yani dan memperoleh ethical approval dengan nomor 01/KEPK/XII/2019.

\section{Pengolahan dan Analisis Data}

Analisa data uni variasi untuk melihat nilai rata-rata pre-test post-test kadar bilirubin serum total kedua kelompok. Hasil uji normalitas menggunakan KolmogorovSmirnov test menunjukan data berdistribusi normal sehingga analisa untuk melihat nilai rata-rata kadar bilirubin serum total digunakan paired t-test dan untuk melihat selisih nilai rata-rata post-test antara kedua kelompok menggunakan uji independent $t$ test.

\section{HASIL}

Tabel 1. Perbedaan Rata-Rata (Mean) Nilai Kadar Bilirubin Serum Total Pada Kelompok Kontrol

\begin{tabular}{llcc}
\hline Variabel & pengukuran & Mean & p-value \\
\hline Nilai & Sebelum & & \\
Kadar & Perawatan & 15,23 & \multirow{2}{*}{0,000} \\
\cline { 2 - 2 } $\begin{array}{l}\text { Bilirubin } \\
\text { Total }\end{array}$ & Sesudah & & \\
Serum & Perawatan & 11,24 & \\
& & & \\
\cline { 2 - 3 } & &
\end{tabular}

Sumber data: hasil uji data penelitian 2020

Kelompok kontrol dalam penelitian ini berguna sebagai pembanding yaitu responden yang mendapat terapi cahaya dan perawatan standar rutin di ruangan perinatologi RS Dustira Kota Cimahi, didapatkan hasil $p$-value sebesar 0,000.

\begin{tabular}{|c|c|c|c|}
\hline \multicolumn{4}{|c|}{$\begin{array}{c}\text { Tabel 2. Perbedaan Rata-Rata Nilai Kadar } \\
\text { Bilirubin Serum Total Pada Kelompok } \\
\text { Intervensi }\end{array}$} \\
\hline Variable & Pengukuran & Mean & $p$-value \\
\hline \multirow{2}{*}{$\begin{array}{l}\text { Nilai } \\
\text { kadar } \\
\text { bilirubin } \\
\text { serum } \\
\text { total }\end{array}$} & $\begin{array}{l}\text { Sebelum } \\
\text { intervensi }\end{array}$ & 15,99 & \\
\hline & $\begin{array}{l}\text { Setelah } \\
\text { intervensi }\end{array}$ & 9,17 & 0,000 \\
\hline
\end{tabular}

Sumber data: hasil uji data penelitian 2020

Hasil uji paired t-test (uji dependen ttest) tentang efektivitas caring support NEOBIL terhadap perubahan nilai kadar bilirubin serum total dalam tabel di atas, pada kelompok intervensi didapatkan nilai p-value 0,000 (nilai $\mathrm{p}<0,05$ ). 
Tabel 3. Perbandingan Selisih Penurunan Rata-Rata Nilai Kadar Bilirubin Serum Total pada Kelompok Kontrol dan Intervensi

\begin{tabular}{|c|c|c|c|c|c|}
\hline Variabel & Kelompok & $\mathrm{N}$ & Mean & Mean difference & $p$-value \\
\hline \multirow{2}{*}{$\begin{array}{l}\text { Kadar } \\
\text { bilirubin }\end{array}$} & Kontrol & 29 & 11,24 & \multirow[t]{2}{*}{2,68} & \multirow[t]{2}{*}{0,002} \\
\hline & Intervensi & 29 & 9,17 & & \\
\hline
\end{tabular}

Sumber data: hasil uji data penelitian 2020

Terjadi penurunan rata-rata nilai kadar bilirubin serum total antara post-test kelompok kontrol dan kelompok intervensi. Berdasarkan hasil uji independen t-test didapatkan hasil $p$-value 0,002 dimana nilai $\mathrm{p}<0,05$.

Data disajikan dalam tiga bentuk, yaitu Tabel, Grafik atau Gambar dan Narasi. Namun yang perlu diingat bahwa untuk satu jenis data hanya boleh disajikan dalam salah satu bentuk, tidak boleh data yang sama disajikan dalam tabel dan juga dalam bentuk grafik. Semua isi artikel harus ditulis dengan jarak satu spasi, indentasi: $1 \mathrm{~cm}$, font: Times New Roman 12 regular.

\section{PEMBAHASAN}

Berdasarkan hasil perhitungan statistik didapatkan bahwa pada derajat kepercayaan 95\% terdapat perbedaan yang signifikan antara nilai kadar bilirubin pre-test dan posttest diberikan intervensi terapi caring support NEOBIL pada kelompok intervensi, dengan nilai sig. 2 tailed sebesar 0,000 < 0,05 (p 0,000). Sedangkan pada kelompok kontrol yang mendapatkan terapi cahaya dan perawatan standar rutin di ruangan, didapatkan p-value sama yaitu p 0,000 artinya, pada kelompok kontrol juga terdapat perbedaan yang bermakna antara nilai kadar bilirubin serum total sebelum dan sesudah pemberian terapi cahaya dan pemberian perawatan standar rutin hyperbilirubinemia.

Adanya perbedaan yang signifikan pada nilai rata-rata (mean) kadar bilirubin serum total sebelum dan sesudah pemberian intervensi antara kedua kelompok merupakan hal yang sangat mungkin terjadi karena kedua kelompok tersebut sama-sama diberikan intervensi atau perawatan baik itu perawatan standar untuk kelompok kontrol atau perawatan yang diberikan oleh peneliti untuk kelompok intervensi, dengan ini kedua intervensi sama-sama mampu menurunkan nilai kadar bilirubin serum total pada neonatus hyperbilirubinemia fisiologis.

Hasil uji statistik independent sampel test untuk melihat selisih rata-rata nilai bilirubin serum total dengan tingkat kepercayaan 95\% setelah diberikan intervensi untuk kedua kelompok didapatkan nilai p-value sebesar 0,002 < 0,05 maka dapat ditarik kesimpulan, terdapat perbedaan selisih rata-rata hasil nilai kadar bilirubin serum total antara kelompok kontrol dan kelompok intervensi, dengan nilai rata-rata post-test kontrol sebesar 11,24 dan post-test intervensi sebesar 9,17 dengan perbedaan rata-rata diantara kedua kelompok tersebut sebesar 2,68. Hasil penelitian menunjukan bahwa pemberian intervensi caring support NEOBIL lebih efektif terhadap penurunan nilai kadar bilirubin serum total. Maka penerapan intervensi caring support NEOBIL bersama dengan fototerapi secara statistic lebih baik dalam menurunkan nilai kadar bilirubin serum total hyperbilirubinemia fisiologis neonatus.

Pada penelitian field massage yang diberikan 2 kali dalam sehari (pagi dan sore) terhadap perubahan bilirubin serum, nilai rata-rata bilirubin serum total setelah pemberian intervensi pada kelompok intervensi mengalami penurunan yang signifikan (Novianti et al., 2018). Manipulasi sentuhan terhadap penurunan kadar bilirubin serum berpengaruh dengan meningkatkan frekuensi buang air besar pada neonatus (Lei et al., 2018).

Terapi massage yang dikombinasikan dengan terapi cahaya dapat mengurangi kadar bilirubin serum dengan meningkatan 
frekuensi buang air besar pada neonatus, hal ini juga dapat memfasilitasi hubungan emosional yang lebih baik antara ibu dan bayi (Aboel-Magd et al., 2017; Babaei \& Vakiliamini, 2018; Gürol \& Polat, 2012; Lin et al., 2015).

Pengaruh positioning terhadap penuruanan kadar bilirubin yang diberikan per 3 jam sekali pada kelompok intervensi mengalami penurunan kadar bilirubin serum lebih cepat dari pada kelompok kontrol. Kondisi ini disebabkan kadar bilirubin dapat diisomerasi oleh sinar fototerapi secara merata keseluruhan bagian tubuh neonatus (Wikanthiningtyas \& Mulyanti, 2016). Luasnya area tubuh bayi yang terpapar cahaya membawa dampak pengobatan lebih baik dibandingkan banyaknya jumlah lampu yang digunakan (American Academy of Pediatrics Subcommittee on Hyperbilirubinemia, 2004).

\section{KESIMPULAN DAN SARAN}

Berdasarkan hasil analisa, perhitungan secara statistik dan didukung hasil penelitian sebelumnya dapat disimpulkan bahwa penurunan nilai kadar bilirubin serum total pada kelompok yang diberikan intervensi caring support NEOBIL lebih efektif dibandingkan dengan kelompok yang diberikan perawatan standar rutin di ruangan saja. Kondisi ini sangat mungkin terjadi karena perawatan pada kelompok intervensi menggabungkan tiga intervensi keperawatan dalam satu kali pemberian perawatan, bounding dengan cara stimulus touch, feeding management dan positioning yang diberikan secara rutin dan teratur.

Hasil penelitian ini dapat memperkaya khasanah keilmuan keperawatan khususnya dalam area keperawatan anak. Institusi pendidikan keperawatan dapat mengembangkan praktik berbasis fakta dan intervensi keperawatan yang aman dan sesuai dengan keperluan perawatan di lapangan. Dapat pula dikembangkan berbagai intervensi keperawatan yang dikombinasikan dengan berbagai terapi medis lainya, menjadi satu penerapan perawatan untuk diaplikasikan secara bersamaan.

\section{DAFTAR PUSTAKA}

Aboel-Magd, A., Masoed, S., Salma Zoheir, \&, \& Houchi, E. L. (2017). Effect of massage on health status of neonates with hyperbilirubinemia. In International Journal of Research in Applied, Natural and Social Sciences (IMPACT: IJRANSS) ISSN(P (Vol. 5). Google Scholar

American Academy of Pediatrics Subcommittee on Hyperbilirubinemia. (2004). Management of hyperbilirubinemia in the newborn infant 35 or more weeks of gestation. In Pediatrics (Vol. 114, Issue 1, pp. 297316).

Pediatrics. https://doi.org/10.1542/peds.114.1.297

Andaruni, N. Q. R., \& Alasiry, E. (2018). Pengaruh pijat bayi dan breastfeeding terhadap penurunan kadar bilirubin pada neonatus dengan hiperbilirubinemia. Jurnal Ilmiah Bidan, 3(2), 45-51. Garuda

Ayuningtyas, I. F. (2019). Kebidanan Komplementer. Pustaka Baru Press. Indonesia Onesearch

Babaei, H., \& Vakiliamini, M. (2018). Effect of Massage Therapy on Transcutaneous Bilirubin Level in Healthy Term Neonates: Randomized Controlled Clinical Trial. Iranian Journal of Neonatology, 9(4), 41-46. https://doi.org/10.22038/ijn.2018.2890 6.1386

Badan Kependudukan dan Keluarga Berencana Nasional, Badan Pusat Statistik, Kementerian Kesehatan, \& USAID. (2018). Survei Demografi dan Kesehatan Indonesia 2017. Google Scholar

Gürol, A., \& Polat, S. (2012). The effects of baby massage on attachment between mother and their infants. Asian Nursing Research, 6(1), 35-41. https://doi.org/10.1016/j.anr.2012.02.0 06

Kianmehr, M., Moslem, A., Moghadam, 
K. ., Naghavi, M., Noghabi, S. ., \& Moghadam, M. . (2014). the effect of massage on serum bilirubin levels in term neonates with hyperbilirubinemia undergoing phototerapy. Nautilus, 128(1), 36-41. Google Scholar

Lei, M., Liu, T., Li, Y., Liu, Y., Meng, L., \& Jin, C. (2018). Effects of massage on newborn infants with jaundice: A metaanalysis. International Journal of Nursing Sciences, 5(1), 89-97. https://doi.org/10.1016/j.ijnss.2018.01. 004

Lin, C. H., Yang, H. C., Cheng, C. S., \& Yen, C. E. (2015). Effects of infant massage on jaundiced neonates undergoing phototherapy. Italian Journal of Pediatrics, 41(94). https://doi.org/10.1186/s13052-0150202-y

Muchowski, K. . (2014). Evaluation and treatment of neonatal hyperbilirubinemia. American Family Physician, 89(11), 873-878. Google Scholar

Ningsih, E. A. (2017). Perubahan posisi pada neonatus dengan masalah hiperbilirubinemia dengan tindakan foto terapi di ruang melati rsud prof. $d r$. margono seokarjo purwokerto [STIKes Muhammadiyah Gombong]. Google Scholar

Novianti, N., Mediani, H. S., \& Nurhidayah, I. (2018). Pengaruh Field Massage sebagai Terapi Adjuvan terhadap Kadar Bilirubin Serum Bayi Hiperbilirubinemia. Jurnal Keperawatan Padjadjaran, 5(3), 315327. https://doi.org/10.24198/jkp.v5i3.654

Prasetyorini, H., \& Sukesi, N. (2018). Pemberian pijat bayi dan sari daun katuk dalam meningkatkan bounding attachment. Jurnal Keperawatan, 10(3), 209-215. https://doi.org/10.32583/keperawatan. 10.3.2018.209-215

Ullah, S., Rahman, K., \& Hedayati, M. (2016). Hyperbilirubinemia in neonates: Types, causes, clinical examinations, preventive measures and treatments: A narrative review article. Iranian Journal of Public Health, 45(5), 558-568. Google Scholar

Wikanthiningtyas, N. W., \& Mulyanti, S. (2016). Pengaruh Alih Baring Selama Fototerapi Terhadap Perubahan Kadar Bilirubin Pada Ikterus Neonatorum di Ruang HCU Neonatus RSUD Dr. Moewardi. (JKG) Jurnal Keperawatan Global, 1(1), 51-54. https://doi.org/10.37341/jkg.v1i1.17

Wong, D. L., Hockenberry-Eaton, M., Wilson, D., Winkelstein, M. L., \& Schwartz, P. (2009). Buku Ajar Keperawatan Pediatrik Wong 2 (6th ed.). EGC. Indonesia Onesearch

\section{INFORMASI TAMBAHAN}

\section{Lisensi}

Hakcipta ( $)$ Heriyanti, An'nisaa dkk. Artikel akses terbuka ini dapat disebarkan seluas-luasnya sesuai aturan Creative Commons Attribution-ShareAlike 4.0 International License dengan catatan tetap menyebutkan penulis dan penerbit sebagaimana mestinya.

\section{Catatan Penerbit}

Poltekkes Kemenkes Kendari menyatakan tetap netral sehubungan dengan klaim dari perspektif atau buah pikiran yang diterbitkan dan dari afiliasi institusional manapun.

\section{Pendanaan}

Penulis tidak menerima pendanaan yang sifatnya spesifik untuk kajian ini.

\section{Konflik Kepentingan}

Penulis tidak memiliki konflik kepentingan. 


\section{Kontribusi Penulis}

Conceptualization

Data curation

Formal analysis

Funding acquisition

Investigation

Methodology

Project administration

Resources

Supervision

Validation

Visualization

Writing - original draft

Writing - review \& editing

\section{Artikel DOI}

https://doi.org/10.36990/hijp.vi.154
: An'nisaa Heriyanti, Restuning Widiasih, Murtiningsih

: An'nisaa Heriyanti

: An'nisaa Heriyanti

: An'nisaa Heriyanti

: An'nisaa Heriyanti

: An'nisaa Heriyanti

: An'nisaa Heriyanti

: An'nisaa Heriyanti

: An'nisaa Heriyanti, Restuning Widiasih, Murtiningsih

: An'nisaa Heriyanti

: An'nisaa Heriyanti

: An'nisaa Heriyanti, Restuning Widiasih, Murtiningsih

: An'nisaa Heriyanti, Restuning Widiasih, Murtiningsih 